\title{
Coxiella burnetii seroprevalence of shepherds and their flocks in the lower Saint-Lawrence River region of Quebec, Canada
}

\author{
Patrick Dolcé MD FRCPC ${ }^{1}$, Marie-Joële Bélanger $\mathrm{BSc}^{1}$, Krzysztof Tumanowicz DVM PhD ${ }^{2}$, Claude $\mathrm{P}$ Gauthier $\mathrm{MD}^{3}$, \\ Philippe Jutras MD FRCPC ${ }^{1}$, Richard Massé MSc MD FRCPC ${ }^{3}$, Claude Montpetit PhD ${ }^{4}$, Harold Bernatchez MD FRCPC ${ }^{1}$, \\ Dorothy McColl $\mathrm{MSc}^{5}$, Harvey Artsob $\mathrm{PhD}^{5}$
}

\begin{abstract}
P Dolcé, M-J Bélanger, K Tumanowicz, et al. Coxiella burnetii seroprevalence of shepherds and their flocks in the lower Saint-Lawrence River region of Quebec, Canada. Can J Infect Dis $2003 ; 14(2): 97-102$.
\end{abstract}

OBECTIVE: To determine the seroprevalence of Coxiella burnetii among the shepherds and their sheep in the lower Saint-Lawrence River region (LSLRR) of Quebec, Canada.

DESIGN: A prospective human-animal comparative study was conducted with 81 shepherds from 46 farms and a control group matched for sex and age. All participants answered a standardized questionnaire to evaluate their risk factors for $Q$ fever, including a specific section on the work practices of the shepherds. All human subjects had a blood sample taken for serology to phase I and phase II antigens of $\mathrm{C}$ burnetii performed by indirect immunofluorescence assay. At each participating farm, seven to nine sheep had blood samples taken for C burnetii serology to be assessed by the complement fixation test.

RESULTS: The seroprevalence to C burnetii was higher in the group of shepherds $(28.4 \%)$ than the control group $(1.2 \%) \quad(\mathrm{P}<0.005)$. Among the group of shepherds, spending more than $5 \mathrm{~h} /$ week in the sheep barn $(\mathrm{P}=0.06)$ and buying and/or trading sheep within the past six months $(\mathrm{P}=0.004)$ were associated with positive $\mathrm{C}$ burnetii serology. A total of 137 of 334 sheep (41\%) were seropositive for $C$ burnetii. These positive sheep were distributed in 41 of the 46 flocks (89\%). No correlation could be demonstrated between a serology for $\mathrm{C}$ burnetii in the herds and the shepherds.

CONCLUSION: $Q$ fever is highly prevalent in the LSLRR of Quebec, affecting 89\% of the flocks and 28\% of the shepherds. Shepherds in this region are at increased risk for $\mathrm{C}$ burnetii infection in comparison to the general population.

Key Words: Coxiella burnetii; Flock; Q fever; Quebec; Serology; Seroprevalence; Sheep; Shepherd

\section{La séroprévalence de Coxiella burnetii chez les bergers et leurs troupeaux dans la région du Bas-Saint-Laurent, au Québec (Canada).}

OBJECTIF : Déterminer la séroprévalence de Coxiella burnetii chez les
bergers et leurs troupeaux dans la région du Bas-Saint-Laurent, au
Québec. Québec. menée de façon prospective auprès de 81 bergers provenant de 46 fermes et d'un groupe témoin apparié selon l'âge et le sexe. Tous les participants ont rempli un questionnaire uniformisé afin d'évaluer leurs facteurs de risque de fièvre $Q$; une section en particulier portait d'ailleurs sur, les pratiques de travail des bergers. Un prélèvement de sang a été effectué chez tous les sujets humains pour un test sérologique à la recherche d'antigènes de C. burnetii de phase I ou II au moyen de l'immunofluorescence indirecte. Un prélèvement de sang a aussi été effectué sur 7 à 9 moutons dans chacune des fermes participantes pour un test sérologique à la recherche de C. burnetii au moyen, cette fois, du test de fixation du complément.

RÉSULTATS : La séroprévalence de C. burnetii s'est révélée plus forte chez les bergers $(28,4 \%)$ que chez les sujets témoins $(1,2 \%)(\mathrm{P}<0,005)$. Dans le groupe de bergers, le fait de passer plus de $5 \mathrm{~h} / \mathrm{sem}$. à la ferme $(\mathrm{P}=0,06)$ et d'acheter des moutons ou d'en faire le commerce au cours des six derniers mois $(\mathrm{P}=0,004)$ a été associé à un test sérologique positif. Quant aux moutons, 137 sur 334 (41\%) ont eu des résultats positifs; les animaux infectés étaient répartis dans 41 fermes sur 46 (89\%). Aucune corrélation n'a été établie quant aux tests sérologiques entre les troupeaux et les bergers.

CONCLUSION : La prévalence de la fièvre $Q$ est élevée dans la région du Bas-Saint-Laurent; elle touche $89 \%$ des troupeaux et $28 \%$ des bergers. Les bergers de la région sont donc plus exposés à l'infection à C. burnetii que la population en général.

$\mathrm{Q}$ ever is a worldwide zoonosis caused by an intracellular rickettsial agent, Coxiella burnetii. This bacteria shows a characteristic phase conversion: the virulent phase I is directly isolated from infected animals, and the avirulent phase II is obtained after successive passages on cellular cultures of embryonated eggs $(1,2)$. Q fever is predominantly transmitted to humans by inhalation of contaminated aerosols from infected animal litters (3-5). The parturition products and the feces and urine of sheep, cats, goats and dogs are the more common

sources of transmission of the bacteria (6-9). Although these animals rarely show any symptoms of the infection $(10,11)$, abortions in sheep, goats and cattle can be seen in some cases $(5,6,12-14)$.

Human $Q$ fever is often asymptomatic or manifests as a mild illness. Atypical pneumonia and hepatitis are the principal clinical manifestations of the acute symptomatic infection, while endocarditis is the most frequent presentation of chronic $Q$ fever $(1,3,15,16)$. Very few studies in North America have

${ }^{1}$ Department of Medical Microbiology and Infectious Diseases, Centre Hospitalier Régional de Rimouski, Rimouski; ${ }^{2}$ Department of Public Health of Lower Saint-Lawrence River Region of Quebec, Rimouski; ${ }^{3}$ Ministère de l'Agriculture, des Pêcheries et de l'Alimentation du Québec, Quebec; ${ }^{4}$ Institut Armand-Frappier, Montreal, Quebec; ${ }^{5}$ National Microbiology Laboratory, Health Canada, Winnipeg, Manitoba

Correspondence and reprints: Dr P Dolcé, Department of Medical Microbiology and Infectious Diseases, Centre Hospitalier Régional de Rimouski, 150, Rouleau, Rimouski, Quebec G5L 5T1. Telephone 418-724-8336, fax 418-724-8619, e-mail pdolce@ssss.gouv.qc.ca Received for publication February 26, 2002. Accepted September 12, 2002 
addressed the issues of prevention of $\mathrm{Q}$ fever. In Australia, a highly effective vaccine (Q-Vax, Commonwealth Serum Laboratories, USA) is available for workers with occupational exposition to C burnetii $(17,18)$.

Seroprevalence studies conducted in Canada have shown that $5 \%$ to $36 \%$ of blood donors $(19,20), 20 \%$ of slaughterhouse workers of the Mauricie region of Quebec (12), 25\% of personnel of the animal pathology laboratory in Rimouski in the lower Saint-Lawrence River region (LSLRR) (M Rochette, unpublished data) and $49 \%$ of veterinarians in Nova Scotia (21) were positive for $\mathrm{C}$ burnetii.

Epizootiological studies have also been done on animal populations in Canada. A seroprevalence study in the Mauricie region of Quebec showed that $\mathrm{C}$ burnetii had infected $26.7 \%$ of the cats, $11.5 \%$ of the cattle and $7.7 \%$ of the sheep (22). Cats were reported as important vectors of transmission of $\mathrm{C}$ burnetii to humans in the Mauricie region of Quebec and in Nova Scotia $(23,24)$. In Ontario, a seroprevalence study demonstrated that $21.3 \%$ of the sheep were positive for antibodies to $\mathrm{C}$ burnetii (25).

Q fever is a notifiable disease in Quebec. From January 1990 to December 1998, 43 (36.1\%) of 119 reported cases were from the LSLRR, which had the highest incidence rate of the province, although it represents only $5 \%$ of the population. A review of the cases of $Q$ fever from the LSLRR between 1991 and 1999 showed that 67\% of the Q fever cases were related to exposure to sheep (P Jutras, unpublished data). It is noteworthy that an important rise in the number of sheep was observed in LSLRR, with an increase from 11,000 animals distributed in 110 flocks in 1983, to more than 33,000 in 180 flocks in 1999 (Union des producteurs agricoles of Quebec, personal communication).

To evaluate the association between $Q$ fever and exposure to ovine in the LSLRR, a prospective human-animal seroprevalence study was undertaken to compare the seroprevalence of $\mathrm{C}$ burnetii between the shepherds, their flocks and the general population. The work practices of the shepherds were also evaluated.

\section{MATERIALS AND METHODS}

Between July and August 1998, all adult shepherds from the 160 registered farms of the LSLRR were asked to participate in this human-animal seroprevalence study, with a maximum of three shepherds and nine sheep per farm. Sera from the shepherds and their sheep were taken during a single visit to the farm.

\section{Humans}

A total of 81 shepherds from 46 farms were enrolled in this study. A control group of 81 participants, matched for age and sex, was recruited from the patients attending a sexually transmitted diseases (STDs) clinic and employees and volunteers of the Centre Hospitalier Régional de Rimouski (CHRR). All participants provided written informed consent. This study was approved by the ethics committee of the CHRR.

Human serology: The human blood samples were delivered within $4 \mathrm{~h}$ of collection to the microbiology laboratory, where the sera were separated by centrifugation. The sera were stored frozen at $-30^{\circ} \mathrm{C}$ before shipping to the National Microbiology Laboratory (NML) in Winnipeg, Manitoba. Immunoglobulin (Ig) $\mathrm{G}$ antibodies against $\mathrm{C}$ burnetii phase I and phase II were assessed at the NML by the standard indirect immunofluorescence assay (IFA) method using antigens of the Nine Mile strain of $\mathrm{C}$ burnetii. An initial screening was done at a dilution of 1:32. All human sera were encoded before testing.

Determination of C Burnetii phase I and II antibodies

Preparation of slides: C burnetii phase I and II antigens were obtained from the Centers for Diseases Control and Prevention $(\mathrm{CDC})$ in Atlanta, Georgia and were yolk sac propagated Nine Mile strain antigens inactivated by gamma irradiation and blended in sufficient phosphate buffered saline ( $\mathrm{pH} 7.6)$ to form an optimal working antigen suspension containing $0.2 \%$ sodium azide as a preservative. The lyophilized phase II antigen was reconstituted with $0.5 \mathrm{~mL}$ of distilled water as per CDC's protocol. The frozen phase I antigen was thawed before use. Two microlitres of antigen slurry were applied to each well of a 12-well slide (Fisher Scientific, Napean) and air-dried for $1 \mathrm{~h}$. The antigen was cold acetone-fixed for $15 \mathrm{~min}$, briefly air dried and stored at $-80^{\circ} \mathrm{C}$. Slides were used at room temperature.

Preparation of clinical specimens: For initial screening, specimens were diluted 1:32 in FTA Hemagglutination Buffer (Becton Dickinson, USA). Positive sera were serially titrated twofold to the endpoint dilution. Ten microlitres of the diluted specimens were added to each well of a 12 -well slide. The slide was incubated at $37^{\circ} \mathrm{C}$ for $1 \mathrm{~h}$ in a humid chamber, followed by a 15 -min wash in FTA buffer and air-dried.

Ten microlitres of conjugate (Sigma goat anti-human FITCconjugated whole molecule IgG diluted 1:32 in conjugate dilution buffer [FTA buffer: Evan's Blue Dye at a dilution of 10:1]) were added to each well. The slide was incubated at $37^{\circ} \mathrm{C}$ for $1 \mathrm{~h}$ in a humid chamber, followed by a 15 -min wash in FTA buffer and airdried.

Three small drops of mounting medium (PBS: glycerol at a dilution of 1:10) were spotted on the surface of the slide, which was then covered with a $22 \times 60 \mathrm{~mm}$ coverslip (Fisher Scientific) and examined with a Zeiss Axiophot (Zeiss, Germany) 2 fluorescent microscope (20x objective).

This method has been described elsewhere $(26,27)$. Antibody titres of 1:32 to C burnetii phase I and/or phase II antigens were considered to be positive. Only IgG antibodies were determined.

Questionnaire: All participants answered a standardized questionnaire that included parameters such as demographic data, history of prior $\mathrm{Q}$ fever infection and exposure to sheep, cattle, goats and cats. The questionnaire also had a section on the work practices of the shepherds and the characteristics of their flocks. This questionnaire is available upon request from the primary author.

\section{Animals}

At each participating farm, blood was drawn from seven to nine adult sheep. After separation, the sera were kept frozen at $-18^{\circ} \mathrm{C}$ before testing. The sera were tested for antibodies to C burnetii by the complement fixation test, using a commercial kit (Hoechst-Behring, Germany) at the Armand Frappier Laboratory in Montreal, Canada. The initial testing was done at a dilution of $1: 8$. Samples with titres of $1: 8$ were serially titrated twofold up to 1:128.

\section{Statistics}

Data were analyzed using EPI-INFO 6.02 software (Centers for Disease Control and Prevention, USA). Comparisons were done using the Mantel-Haenszel $\chi^{2}$, and the Fisher exact test when appropriate. All $\mathrm{P}$ values were two-sided, and $\mathrm{P} \leq 0.05$ was considered statistically significant. 
TABLE 1

Demographic data of the shepherds and control participants, and their serology results to Coxiella burnetii

\begin{tabular}{lcccc}
\hline & $\begin{array}{c}\text { Shepherds } \\
(\mathbf{n}=\mathbf{8 1})\end{array}$ & $\begin{array}{c}\text { Control } \\
(\mathbf{n}=\mathbf{8 1})\end{array}$ & Total & $\mathbf{P}$ \\
\hline Male & 47 & 47 & 94 & $\mathrm{NS}$ \\
Female & 34 & 34 & 68 & $\mathrm{NS}$ \\
Age Average & 40 & 40 & & $\mathrm{NS}$ \\
$\begin{array}{l}\text { Residence in } \\
\text { rural community }\end{array}$ & $78(96 \%)$ & $25(31 \%)$ & & $<0.00001$ \\
$\begin{array}{l}\text { Positive serology } \\
\text { to C burnetii }\end{array}$ & $23(28 \%)$ & $1(1 \%)$ & 24 & $<0.00001$ \\
\hline
\end{tabular}

NS Not significant

\section{RESULTS}

Both shepherd and control groups were comparable for age and sex, but more participants in the shepherd group were residents of rural communities than in the control group (Table 1 ).

Significantly more shepherds ( 23 of $81,28 \%$ ) were seropositive to phase I and/or II of C burnetii antigens compared with only one participant $(1.2 \%)$ in the control group $(\mathrm{P}<0.00005)$. The 23 positive shepherds were distributed from 20 different farms scattered throughout the territory of LSLRR. Only one seropositive shepherd had been previously diagnosed with acute symptomatic Q fever in 1996. All other positive cases had not been previously recognized and had presumably mild or asymptomatic infections.

The only seropositive case in the control group reported a single visit to a sheep farm within the past year before testing. Seven other participants among the control group had mentioned recent visits to sheep farms, including a veterinarian who had more than 50 such visits. The profiles of the 24 positive sera are presented in Table 2 . No serological result was suggestive of chronic $Q$ fever because chronic $Q$ fever is characterized by the presence of titres of $1: 800$ or greater to $\mathrm{C}$ burnetii IgG anti-phase I antigens by immunofluorescence (6).

The data on the work practices of the shepherds are shown in Table 3. On most farms, very few appropriate measures were taken with the parturition products, although all farmers reported annual cleaning of the sheep barn. Only 38\% of the shepards disposed of the parturition products in the garbage; disinfection procedures of the site after parturition were applied in less than 5\%; masks were almost never worn by the shepherds; and the parturition products were often left in the sheep barn, and ingested by cats and dogs living on the farm.

Only two factors were found to correlate with the occurrence of positive serology for $\mathrm{C}$ burnetii among the shepherds: spending more than $5 \mathrm{~h}$ weekly on the sheep farm $(\mathrm{P}=0.05)$ and the buying and/or trading of ovine within the past six months $(\mathrm{P}=0.004)$ (Table 3).

A total of 399 sheep were included in this study (average 8.7 sheep per farm). Thirty-one farms had nine participating sheep, 13 farms had eight participating sheep and one farm included only seven participating sheep. Sixty-five (16\%) sheep were excluded from analysis because their sera demonstrated a nonspecific cellular reaction in 62 cases and exhibited anticomplementary activity in three cases. Of the 334 evaluable sheep sera tested, 137 (41\%) were seropositive to $\mathrm{C}$ burnetii. These seroreactive ewes were distributed in 41 of the 46 herds (89\%).
TABLE 2

Results of the seropositive human participants to Coxiella burnetii phase I and phase II antigens

\begin{tabular}{|c|c|c|c|c|}
\hline No & Group & Farm number & Phase I & Phase II \\
\hline 1 & $S$ & 1 & Negative & $1 / 32$ \\
\hline 2 & $S$ & 2 & $1 / 32$ & Negative \\
\hline 3 & $S$ & 3 & $1 / 128$ & Negative \\
\hline 4 & $S$ & 4 & $1 / 32$ & Negative \\
\hline 5 & $S$ & 4 & $1 / 32$ & Negative \\
\hline 6 & $S$ & 5 & Negative & $1 / 32$ \\
\hline 7 & S & 6 & $1 / 32$ & $1 / 64$ \\
\hline 8 & S & 7 & $1 / 64$ & Negative \\
\hline 9 & $S$ & 8 & $1 / 128$ & $1 / 256$ \\
\hline 10 & S & 8 & $1 / 32$ & Negative \\
\hline 11 & $S$ & 9 & $1 / 32$ & Negative \\
\hline 12 & S & 10 & $1 / 128$ & $1 / 32$ \\
\hline 13 & $S$ & 11 & $1 / 128$ & $1 / 256$ \\
\hline 14 & $S$ & 12 & $1 / 32$ & $1 / 32$ \\
\hline 15 & S & 13 & $1 / 32$ & Negative \\
\hline 16 & S & 14 & $1 / 32$ & $1 / 32$ \\
\hline 17 & S & 14 & $1 / 32$ & Negative \\
\hline 18 & $S$ & 15 & $1 / 64$ & Negative \\
\hline 19 & S & 16 & $1 / 64$ & $1 / 32$ \\
\hline 20 & $S$ & 17 & $1 / 32$ & Negative \\
\hline 21 & S & 18 & Negative & $1 / 32$ \\
\hline 22 & $S$ & 19 & $1 / 64$ & $1 / 64$ \\
\hline 23 & S & 20 & $1 / 32$ & $1 / 128$ \\
\hline 24 & $\mathrm{C}$ & $\begin{array}{c}\text { Not } \\
\text { applicable }\end{array}$ & Negative & $1 / 64$ \\
\hline
\end{tabular}

C Control group; S Shepherd group

No association was found between seropositivity in the shepherds and their flocks (Table 4). Most shepherds (72 of 81, $89 \%$ ) worked on farms where the sampled sheep were found to be positive to $\mathrm{C}$ burnetii. Also, the number of seropositive sheep in a flock had no impact on the serology results of the shepherds. Of the nine shepherds working with seronegative sheep, two (22\%) had previous $Q$ fever infections. Surprisingly, all seven shepherds with six or more seropositive sheep in their flock were seronegative to C burnetii.

\section{DISCUSSION}

This study has shown that exposure to $\mathrm{C}$ burnetii is highly prevalent in the shepherds $(28 \%)$ and sheep (41\% of the individual sheep and $89 \%$ of the flocks) in the LSLRR of Quebec. This could explain the higher prevalence of $Q$ fever reported in this region of Quebec and the association of cases with exposure to sheep. In comparison, only $1 \%$ of our human control group demonstrated antibodies to $\mathrm{C}$ burnetii. It would have been of interest to match both test groups for city of residency because $96 \%$ of the shepherds lived in rural communities compared with only $31 \%$ of the control group. The fact that the control population was acquired from employees, volunteers and patients attending the STD clinic, and,therefore, more likely to live in an urban area, makes comparison of the two groups more difficult. Instead, an ideal control population should have been individuals who lived in the same area as the shepherds but who did not work with the sheep. It is known that urban patients have fewer contacts with $\mathrm{C}$ burnetii-associated farm animals (sheep, goats, cattle). Some publications 
TABLE 3

Correlation between the work practices of the shepherds and their serology to Coxiella burnetii

\begin{tabular}{|c|c|c|c|c|c|}
\hline Work practice & & $\begin{array}{c}\text { Negative serology } \\
\mathrm{n}=58 \\
(\mathrm{n}[\%])\end{array}$ & $\begin{array}{c}\text { Positive serology } \\
n=23 \\
(n[\%])\end{array}$ & Total & $\mathbf{P}$ \\
\hline \multirow[t]{4}{*}{ Size of the herd } & $11-50$ ewes & $0 / 58(0)$ & $1 / 23(4.4)$ & $1 / 81(1.2)$ & NS \\
\hline & $51-100$ ewes & $12 / 58(20.7)$ & 4/23 (17.4) & $16 / 81(19.7)$ & NS \\
\hline & $101-301$ ewes & $31 / 58(53.4)$ & $14 / 23(60.9)$ & $45 / 81(55.6)$ & NS \\
\hline & More than 301 ewes & $15 / 58(25.9)$ & 4/23 (17.4) & $19 / 81(23.4)$ & NS \\
\hline \multirow[t]{5}{*}{ Years of work practice } & Less than 1 year & $3 / 57(5.3)$ & $1 / 23(4.4)$ & $4 / 80(5.0)$ & NS \\
\hline & $1-4$ years & $27 / 57(47.4)$ & $12 / 23(52.2)$ & $39 / 80(48.8)$ & NS \\
\hline & $5-9$ years & $12 / 57(21.1)$ & $5 / 23(21.7)$ & $17 / 80(21.2)$ & NS \\
\hline & $10-19$ years & $10 / 57(17.5)$ & 4/23 (17.4) & $14 / 80(17.5)$ & NS \\
\hline & 20 years and more & $5 / 57(8.8)$ & $1 / 23(4.4)$ & $6 / 80(7.5)$ & NS \\
\hline \multirow[t]{2}{*}{ Weekly hours of exposure to sheep } & $\leq 5 \mathrm{~h}$ & $13 / 57(22.8)$ & $1 / 23(4.4)$ & $14 / 80(17.5)$ & 0.05 \\
\hline & $>5 \mathrm{~h}$ & $44 / 57(77.2)$ & 22/23 (95.6) & $66 / 80(82.5)$ & \\
\hline Frequent buying and trading of sheep & & $24 / 57(42.0)$ & 18/23 (78.2) & $42 / 80(52.5)$ & 0.004 \\
\hline Sheep in pasture & & $44 / 58(75.9)$ & $16 / 23(69.6)$ & $60 / 81(74.1)$ & NS \\
\hline Shepherd contact with parturition products & & $56 / 57(98.2)$ & $23 / 23(100)$ & $79 / 80(98.8)$ & NS \\
\hline Isolation of ewes during parturition & & $13 / 58(22.4)$ & $7 / 23(30.4)$ & $20 / 81(24.7)$ & NS \\
\hline Disinfection of the site after parturition & Yes & $1 / 57(1.7)$ & 2/23 (8.7) & $3 / 80(3.8)$ & NS \\
\hline \multirow[t]{3}{*}{ Disposal of parturition products } & Left in the lambing pens & $12 / 58(20.7)$ & $2 / 23(8.7)$ & $14 / 81(17.3)$ & NS \\
\hline & Threw in the garbage & 23/58 (39.6) & $8 / 23(34.8)$ & $31 / 81(38.3)$ & NS \\
\hline & Other & 23/58 (39.6) & $13 / 23(56.5)$ & $36 / 81(44.4)$ & NS \\
\hline Wearing of a mask during parturition & Never & $55 / 56(98.2)$ & 22/23 (95.6) & $77 / 79(97.5)$ & NS \\
\hline $\begin{array}{l}\text { Prevention of contact of cats and dogs } \\
\text { with sheep }\end{array}$ & $15 / 58(25.9)$ & 4/22 (18.2) & $19 / 80(23.7)$ & NS & \\
\hline $\begin{array}{l}\text { Ingestion of the parturition products by cats } \\
\text { and dogs }\end{array}$ & & $37 / 58(63.8)$ & $13 / 22(59.1)$ & $50 / 80(62.5)$ & NS \\
\hline Annual sheepfold cleaning & & $58 / 58(100)$ & $23 / 23(100)$ & $81 / 81(100)$ & NS \\
\hline Sheepfold disinfection & & $24 / 56(42.8)$ & $8 / 23(34.8)$ & $32 / 79(40.5)$ & NS \\
\hline \multirow[t]{3}{*}{ Use of specific clothes in the lambing pens } & Never & $8 / 57(14.0)$ & 2/23 (8.7) & $10 / 80(12.5)$ & NS \\
\hline & Sometimes & $32 / 57(56.1)$ & $17 / 23(73.9)$ & $49 / 80(61.2)$ & NS \\
\hline & Always & $17 / 57(29.8)$ & 4/23 (17.4) & $21 / 80(26.2)$ & NS \\
\hline Drinking of unpasteurized milk & & $18 / 57(31.6)$ & 9/23 (31.1) & $27 / 80(33.8)$ & NS \\
\hline
\end{tabular}

NS Not significant

TABLE 4

Relation between the serology of the shepherds and their flocks

\begin{tabular}{|c|c|c|c|}
\hline $\begin{array}{l}\text { Number of Coxiella burnetii positive } \\
\text { sheep sampled in a flock }\end{array}$ & $\begin{array}{l}\text { Shepherds with serum } \\
\text { positive to } C \text { burnetii }\end{array}$ & $\begin{array}{l}\text { Shepherds with serum } \\
\text { negative to } C \text { burnetii }\end{array}$ & Total \\
\hline 0 & 2 & 7 & 9 \\
\hline $1-2$ & 10 & 23 & 33 \\
\hline $3-5$ & 11 & 21 & 32 \\
\hline$\geq 6$ & 0 & 7 & 7 \\
\hline Total & 23 & 58 & 81 \\
\hline
\end{tabular}

reported higher seroprevalence rates of $11 \%$ to $15 \%$ when the control participants were in rural areas $(10,15,20,28)$.

Seroepidemiological studies of blood donors from other areas of Atlantic Canada suggested that the 'background' seroprevalence was higher $4.2 \%$ in New Brunswick, $8.3 \%$ in Newfoundland, $11.8 \%$ in Nova Scotia and $14.2 \%$ in Prince Edward Island [29-31]). This may reflect an underestimation of the true prevalence because we had a small control group, or alternatively the seroprevalence may be lower in our region. Studies of blood donors in France found an average of $4 \%$ of participants to be positive for $\mathrm{C}$ burnetii antibodies (15). Also, a Japanese study on the prevalence of C burnetii in different groups of workers with occupational risk factors showed the seroprevalence of the healthy control was 1 in 
$60(1.7 \%)$, which is more comparable to our control group (32).

Thomas et al (10) reported a 27\% seroprevalence in different livestock farm workers from the United Kingdom, which is consistent with our data. This study also found a correlation between seroprevalence and the extent of total contact with the farm animals because full-time employees were more likely to be seropositive to $\mathrm{C}$ burnetii than part-time employees. Our shepherds were also more likely to be positive if they worked more than $5 \mathrm{~h}$ weekly. Curiously, the number of years of experience has not been associated with seroprevalence to $\mathrm{C}$ burnetii, but only a small sample of 20 shepherds had more than 10 years of practice.

Trading and buying of sheep was correlated to $Q$ fever in our shepherd population. This could be related to a higher rate of exposure of the shepherds to $\mathrm{C}$ burnetii on multiple farms or to the introduction of $\mathrm{C}$ burnetii with secondary dissemination of the etiological agent within the farm.

The seroprevalence obtained in our sheep was higher than in previous reports. A study from Ontario showed a prevalence of $21.3 \%$ of the sheep flocks tested by ELISA (25), and a serosurvey in Nova Scotia demonstrated positive sera for phase II antigen in $6.7 \%$ of the 329 sheep tested (24). We also examined seroprevalence data for other animals. Seropositivity varied from $23 \%$ to $32 \%$ in the cats of the Mauricie region of Quebec (Monique Goyette, unpublished data), and rates of $12 \%$ and $67 \%$ were found for bovine herds in Mauricie ( $\mathrm{M}$ Goyette, unpublished data) and Ontario (33), respectively. The complement fixation technique is generally considered to be less sensitive than the IFA method, especially for the determination of immunity or past infection; thus the high rates of positive animals in this study may, in fact, be an under-representation of the true number of reactors. In this study, it would have been of great value to include sheep from other regions of Quebec and other animals (cats, cattle and goats) to verify whether

\section{REFERENCES}

1. Raoult D, Marrie TJ. Q fever. Clin Infect Dis 1995;20:489-96.

2. Fiset P, Woodward TE. Q Fever. In: Evans AS, Brachman PS.

Bacterial Infections of Humans: Epidemiology and Control, 2nd edn.

New York: Plenum Publishing Corporation, 1991:547-60.

3. Marrie TJ. Q fever - a review. Can Vet J 1990;31:555-63.

4. Marrie TJ. Coxiella burnetii (Q fever). In: Mandell GL, Bennett JE,

Dolin R. Principles and Practices of Infectious Diseases, 5th edn. New York: Churchill Livingstone, 2000:2043-50.

5. Ludlam H, Wreghitt TG, Thornton S, et al. Q fever in pregnancy. J Infect 1997;34:75-8.

6. Maurin M, Raoult D. Q fever. Clin Microbiol Rev 1999;12:518-23.

7. Buhariwalla F, Cann B, Marrie TJ. A dog-related outbreak of $Q$ fever. Clin Infect Dis 1996;23:753-5.

8. Fournier PE, Marrie TJ, Raoult D. Minireview - Diagnosis of $Q$ fever. J Clin Microbiol 1998:36:1823-34.

9. Simor AE. Q fever: Human disease in Ontario. Can Vet J 1987;28:264-5.

10. Thomas DRH, Treweek L, Salmon RL, et al. The risk of acquiring $Q$ fever on farms: A seroepidemiological study. Occup Environ Med 1995;52:644-7.

11. Thibon M, Villiers V, Souque P, Dautry-Varsat A, Duquesnel R, Ojcius DM. High incidence of Coxiella burnetii markers in a rural population in France. Eur J Epidemiol 1996;12:509-13.

12. Goyette M, Poirier A, Bouchard J, Morrier E. Q fever in Quebec (1989-1993): Report of 14 cases. Can J Infect Dis 1994;5:113-8.

13. Palmer NC, Kierstead M, Key DW, et al. Placentitis and abortion in goats and sheep in Ontario caused by Coxiella burnetii. Can Vet J 1983;24:60-1. such high seroprevalence would have been observed in these cases.

Our farmers had very few adequate preventive measures to limit the propagation of $Q$ fever. Only $38 \%$ threw the parturition products in the garbage. In many cases, they were left in the lambing pens and ingested by cats and dogs living on the farm. Proper preventive measures should be implemented with education of the shepherds on $Q$ fever.

The guidelines should include specific disinfection procedures, the isolation of parturient ewes, the burying or burning of placentas and dead fetuses outside the lambing pen and the use of masks when assisting with parturition. Parturition products should be kept away from domestic animals (cats or dogs) to avoid their ingestion and further dissemination of $Q$ fever. Also, the use of specific clothes in the lambing pen should be encouraged.

Q fever was mostly asymptomatic or not recognized in our shepherds. The role of a vaccine for use by our shepherd population should be examined because such a high seroprevalence rate was documented.

\section{CONCLUSIONS}

$Q$ fever is highly endemic in the LSLRR of Quebec, with a seroprevalence of $28 \%$ in our shepherd population and $89 \%$ in our sheep flocks. Proper preventive measures, especially when in contact with parturition products, are needed to reduce the reservoir for the rickettsial C burnetii and ultimately limit the risk of acquiring $\mathrm{Q}$ fever by our shepherds. Further studies should investigate the prevalence of antibodies to $\mathrm{C}$ burnetii in other sheep flocks in Quebec and evaluate the efficacy of different prevention strategies.

ACKNOWLEDGEMENTS: The authors would like to address special thanks to Pfizer Canada for their financial support of this study.
14. Sanford SE, Josephson GKA, MacDonald A. Q fever abortions in a goat herd. Can Vet J 1993;34:246.

15. Tissot-Dupont H, Raoult D, Brouqui P, et al. Epidemiologic features and clinical presentation of acute $Q$ fever in hospitalized patients: 323 French cases. Am J Med 1992;93:427-34.

16. Marrie TJ, Haldane EV, Faulkner RS, Kwan C, Grant B, Cook F. The importance of Coxiella burnetii as a cause of pneumonia in Nova Scotia. Can J Public Health 1985;76:233-6.

17. Ackland JR, Worswick DA, Marmion BP. Vaccine prophylaxis of Q fever. Med J Aust 1994;160:704-8.

18. Shapiro RA, Siskind V, Schofield FD, Stallman N, Worswick DA, Marmion BP. A randomized, controlled, double-blind, cross-over, clinical trial of $Q$ fever vaccine in selected Queensland abattoirs. Epidemiol Infect 1990;104:267-73.

19. Marrie TJ, Yates L. Incidence of $Q$ fever: Pilot studies in two areas in Nova Scotia. Ann N Y Acad Sci 1990;590:275-80.

20. Marrie TJ, Pollack PT. Seroepidemiology of Q fever in Nova Scotia: Evidence for age dependent cohorts and geographical distribution. Eur J Epidemiol 1995;11:47-54.

21. Marrie TJ, Fraser J. Prevalence of antibodies to Coxiella burnetii among veterinarians and slaughterhouse workers in Nova Scotia. Can Vet J 1985;26:181-4.

22. Morier E, Goyette M, Vallières A, Poirier A, Bouchard J, et al. Séroprévalence de Coxiella burnetti chez les populations animales. Association des médecins microbiologistes infectiologues du Québec. XIXe annual congress, Montreal, Quebec, June 1-3, 1994. [Abst]

23. Vallières A, Goyette M, Bigras-Poulin M, et al. Séroprévalence de Coxiella burnetii au sein d'une population de chats domestiques au 
Québec. Epidémiol santé anim 1996;29:43-9.

24. Marrie TJ, Van Buren J, Fraser J, et al. Seroepidemiology of Q fever among domestic animals in Nova Scotia. Am J Public Health 1985;75:763-6.

25. Lang G, Waltner-Toews D, Menzies P. The seroprevalence of coxiellosis (Q fever) in Ontario sheep flocks. Can J Vet Res 1991;55:139-42.

26. Centers for Disease Control, Department of Health and Human Services, Public Health Service. Indirect fluorescent antibody technique for the detection of Coxiella burnetii antibodies. Atlanta: Centers for Disease Control, US Government Printing Office, 1987.

27. Goyette $\mathrm{M}$, Bouchard J, Poirier $\mathrm{A}$, et al. Importance of $\mathrm{Q}$ fever in community acquired pneumonia. Can J Infect Dis 1996;7:370-3.

28. Lévesque B, De Serres G, Higgins R, et al. Seroepidemiologic study of three zoonoses (leptospirosis, Q fever, and tularemia) among trappers in Québec, Canada. Clin Diagn Lab Immunol 1995;2:496-8

29. Marrie TJ, Van Buren J, Faulkner RS, et al. Seroepidemiology of $\mathrm{Q}$ fever in Nova Scotia and Prince Edward Island. Can J Microbiol 1984;30:129-34.

30. Marrie TJ. Seroepidemiology of $Q$ fever in New Brunswick and Alberta. Can J Microbiol 1988;34:1043-5.

31. Hatchette TF, Hudson RC, Schlech WF, et al. Goat associated $Q$ fever, a new disease in Newfoundland. Emerging Infect Dis 2001;7:413-9.

32. Htwe KK, Yoshida T, Hayashi S, et al. Prevalence of antibodies to Coxiella burnetii in Japan. J Clin Microbiol 1993;31:722-3.

33. Lang GH. Serosurvey on the occurrence of Coxiella burnetii in Ontario cattle. Can J Public Health 1988;79:56-9. 


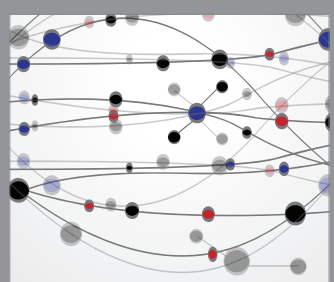

The Scientific World Journal
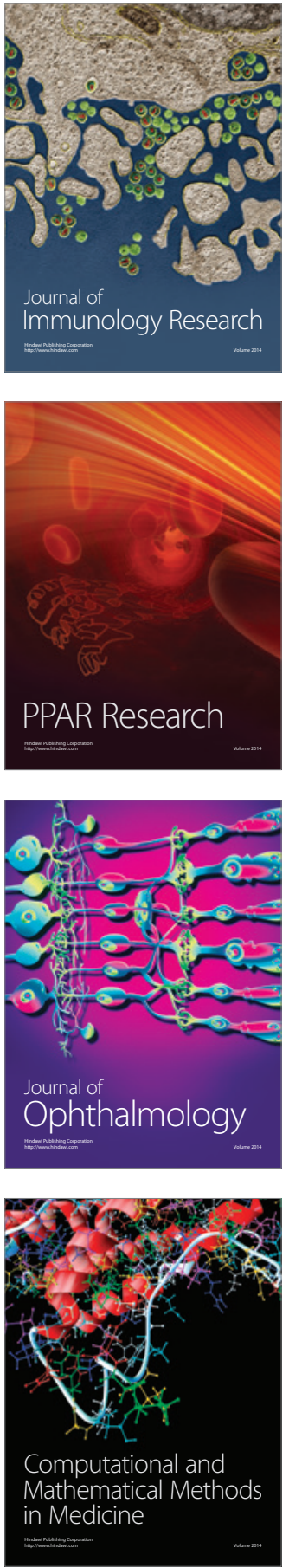

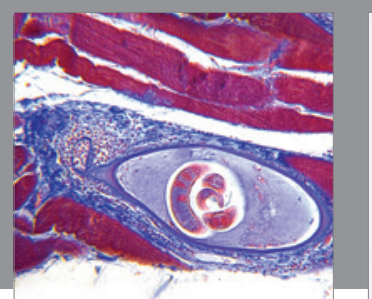

Gastroenterology Research and Practice

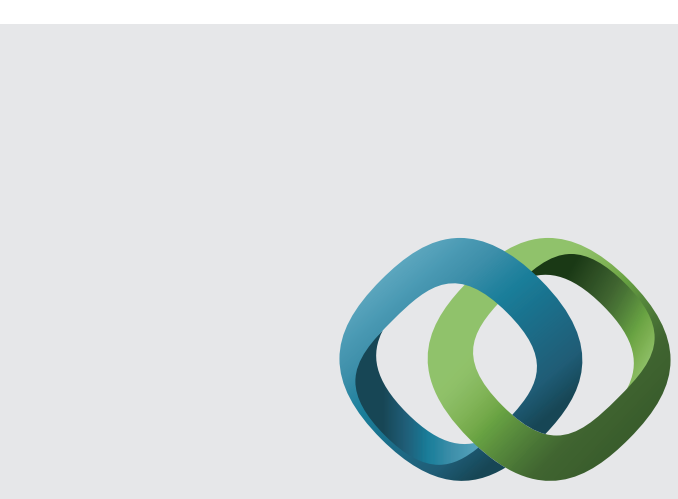

\section{Hindawi}

Submit your manuscripts at

http://www.hindawi.com
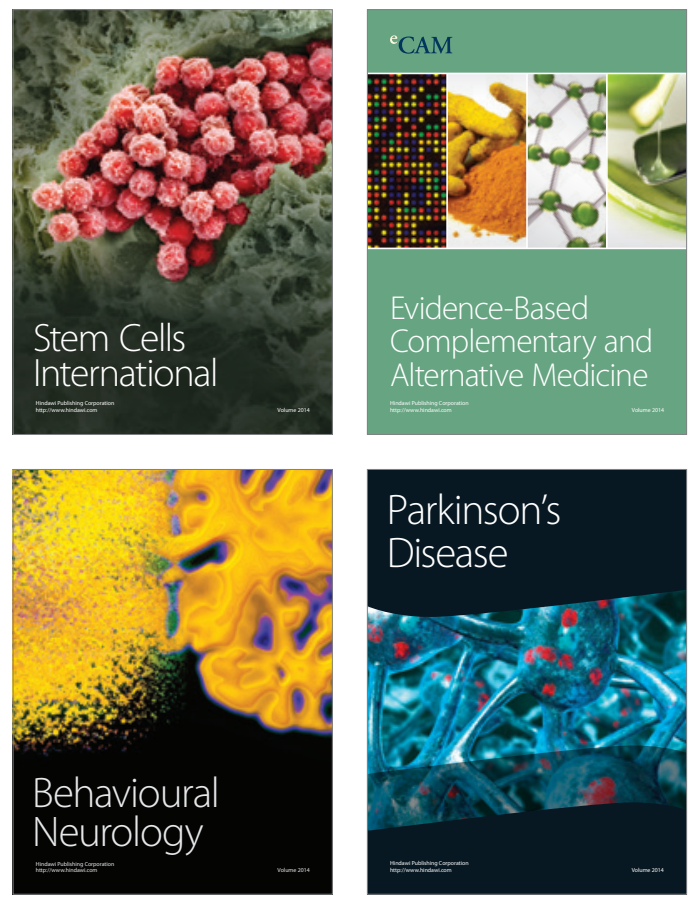
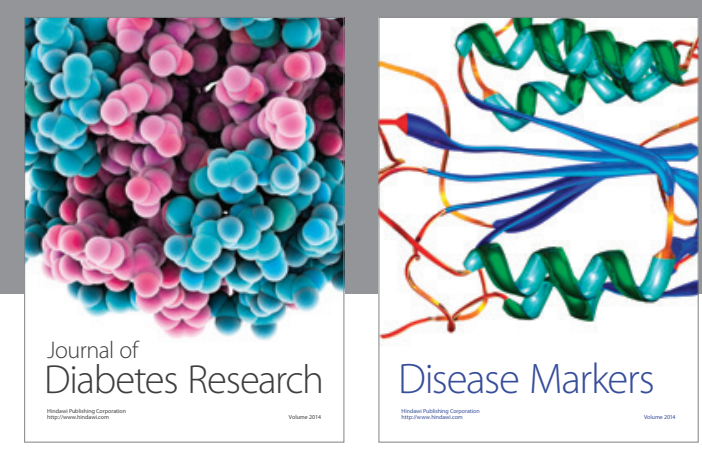

Disease Markers
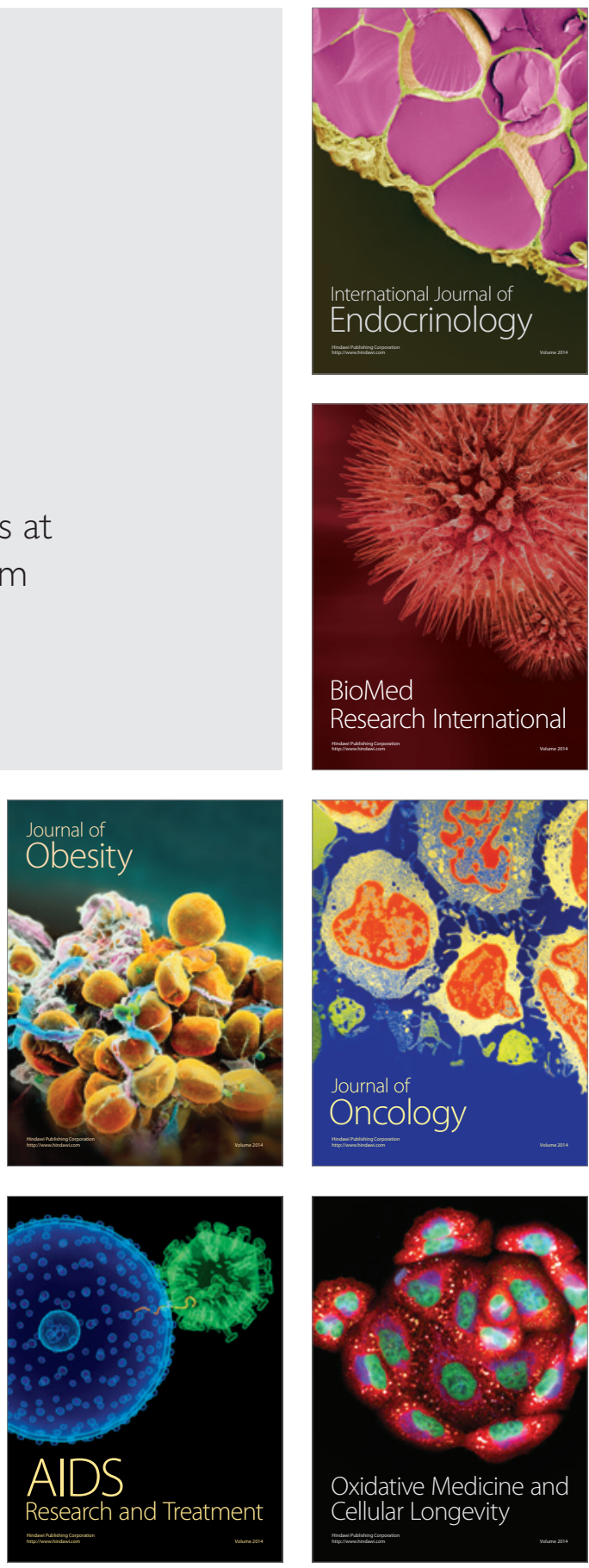